\title{
High-performance Liquid Chromatography Analysis of Nebivolol and Amlodipine and Some Related Compounds in Synthetic Mixture
}

\author{
Nebivolol ve Amlodipin ve Bazı ilgili Bileşiklerinin Sentetik Karışımlarda HPLC \\ ile Analizi
}

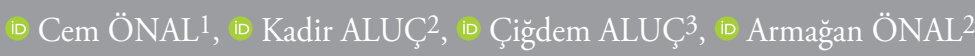

${ }^{1}$ Cinnagen Medicine Company, Project Director, İstanbul, Turkey

2İstanbul University Faculty of Pharmacy, Department of Analytical Chemistry, İstanbul, Turkey

${ }^{3}$ Abdi İbrahim Medicine Company, Production, İstanbul, Turkey

\begin{abstract}
Objective: This study aimed to develop and validate a method using a high-performance liquid chromatography (HPLC) to perform a quantitative analysis of nebivolol (NEB) and amlodipine (AML) along with some related substances in the synthetic mixture.
\end{abstract}

Methods: The separation in the described chromatographic system was accomplished using a mobile phase consisting of a mixture of acetate buffer ( $\mathrm{pH}: 4.5$ ) and acetonitrile and a HPLC C18 column (150 mm x $4.6 \mathrm{~mm}, 2.6 \mu \mathrm{m}$ ) with gradient elution on a consistent flow rate of $1.3 \mathrm{~mL} / \mathrm{min}$. Photodiode array detection was carried out at a wavelength of $265 \mathrm{~nm}$. According to The International Conference on Harmonisation guidelines, the drug was exposed to various stress conditions; including photolysis, oxidation, thermal degradation and hydrolysis under acidic, basic and neutral mediums.

Results: Ranges of detection and quantitation limits were determined to be $0.2-10.0 \mu \mathrm{g} \cdot \mathrm{mL}^{-1}$ and $0.25-10.0 \mu \mathrm{g} \cdot \mathrm{mL}^{-1}$ for NEB and AML, respectively. The relative standard deviation values within and between days precision were determined to be $<2 \%$. For all substances, the average recovery values were determined within the range of $98.00 \%-101.50 \%$.

Conclusion: We conclude that this developed analytical procedure applies to the quality control of drug formulations.

Keywords: Nebivolol, amlodipine, high-performance liquid chromatography, validation, synthetic mixture

\section{ÖZ}

Amaç: Bu çalışma, nebivolol (NEB) ve amlodipinin (AML) kantitatif analizini yapmak için yüksek performanslı sıvı kromatografisi (HPLC) kullanarak bir yöntem geliştirmeyi ve validasyonunu amaçlamıştır

Yöntemler: Kromatografik sistemdeki ayırma, asetat tamponu ( $\mathrm{pH}$ : $4,5)$ ve asetonitril karışımından oluşan bir mobil faz kullanılarak, 1,3 $\mathrm{mL} /$ dakika akış hızında, C18 kolonda $(150 \mathrm{~mm} \times$ x 4,6 mm, 2,6 m) gerçekleştirildi. Diyot sıralı dedektör $265 \mathrm{~nm}$ dalga boyuna ayarlandı. Uluslararası Uyum Konferansı yönergelerine uygun olarak ilaç, çeşitli stres koşullarına maruz bırakılmıştır. Bunlar; fotoliz, oksidasyon, termal bozunma ve asidik, bazik ve nötr ortamlar altında hidrolizdir.

Bulgular: NBV ve AMV için kantitasyon limit aralıkları sırasıyla $0,2-10,0 \mathrm{~g} / \mathrm{mL}^{-1}$ ve $0,25-10,0 \mathrm{~g} / \mathrm{mL}^{-1}$ olarak belirlenmiştir. Gün içi ve günler arası kesinlik bakımından RSD değerlerinin \%2'den düşük olduğu belirlenmiştir. Analizlenen tüm maddeler için ortalama geri kazanım değerlerinin \%98,00-\%101,50 aralığında olduğu belirlenmiştir.

Sonuç: Geliştirilen analitik sürecin ilaç formülasyonlarının kalite kontrolü için uygulanabilir olduğu sonucuna vardık.

Anahtar Sözcükler: Nebivolol, amlodipin, yüksek basınçlı sıvı kromatografisi, validasyon, sentetik karışım

Address for Correspondence: Cem ÖNAL, Cinnagen Medicine Company, Project Director, İstanbul, Turkey

Received: 01.04.2020

E-mail: cemfox@yahoo.com ORCID ID: orcid.org/0000-0002-5840-7386

Cite this article as: Önal C, Aluç K, Aluç Ç, Önal A. High-performance Liquid Chromatography Analysis of Nebivolol and Amlodipine and Some Related Compounds in Synthetic Mixture. Bezmialem Science 2021;9(3):264-70. 


\section{Introduction}

Nebivolol hydrochloride's (NEB) chemical name is (1R)-1[(2R)-6-fluoro-3,4-dihydro-2H-1-benzopyran-2-yl]-2-\{[(2R)-2[(2S)-6-fluoro-3,4-dihydro-2H-1-benzopyran-2-yl]-2-hydroxy ethyl]amino\}ethan-1-ol hydrochloride. NEB hydrochloride is a third-generation antihypertensive drug, acting as a very specific $\beta 1$-blocker. The mechanism of action of the drug substance occurs via its $\beta 1$-receptor blocking activity and nitric oxide potentiation, resulting in its vasodilation effects (1-3).

Amlodipine besylate (AML) is dihydropyridine class calcium channel blocker used via oral route and has the chemical name as follows: 3-ethyl 5-methyl 2-[(2-aminoethoxy) methyl]-4-(2-chlorophenyl)-6-methyl-1, 4-dihydropyridine-3, 5-dicarboxylate; benzenesulfonate (4). AML is used for hypertension management as the first line therapy agent according to therapeutical guidelines based on its suitable adverse event profile and relatively long action. Its mechanism of action involves reducing the calcium ion influx. However, this effect occurs quite selectively on the smooth muscles rather than affecting the cardiac muscle cells. In addition, it does not affect calcium ion mobilisation across the cell membrane, resulting in a reduction in the peripheral vascular resistance and blood pressure $(5,6)$. Concomitant use of NEB and AML for hypertension management is evaluated to be beneficial due to the involvement of mechanisms of action of these two molecules, yielding a synergetic effect in the living organism to lower the blood pressure. Furthermore, lower doses of both molecules are sufficient with this combination therapy.

A literature review was performed and discovered that most of the analytical techniques, employed for determining NEB and AML in the combination formula, were mainly based on spectrophotometry (7-15), high-performance liquid chromatography (HPLC) (16-19) and high-performance thinlayer chromatography (20-22). The quantification of related substances in the combination formula of NEB and AML are individually reported in literature. Based on literature review and current available information, no method which can analyse related substances of simultaneous NEB and AML in combined dosage forms was reported. Related compounds of NEB and AML should be determined in the combination formula of NEB and AML without a need for prior separation for practical reasons. Therefore, our study targeted the development and validation of the developed analytical method to allow quantification of related compounds of NEB and AML in fixed dose combination pharmaceutical dosage forms avoiding any a prior separation procedure.

Some of these related compounds were determined to be possible degradants of AML and NEB in the drug product. This fact, too, shows the need for a method to determine the related compounds of NEB and AML in combined dosage forms without prior separation and supports our aim to develop and validate an analytical method that meets the needs for the combination formula. Method validation for related compounds was accomplished according to the International Conference on

Harmonisation (ICH) requirements, by carrying out stress tests for fixed dose combination tablets covering various conditions; photolysis, oxidation, hydrolysis (at different $\mathrm{pH}$ mediums) and thermal degradation (23). Results obtained out of the stability testing procedures were anticipated to provide important contributions to properly developed manufacturing processes; contributing to decision-making processes for selecting proper packaging and determining the storage conditions, shelf life of the product and expiration date.

\section{Experimental}

\section{Reagents and Solutions}

Working standards of AML and NEB and related compounds were obtained from Hetero Drug Ltd. (Telangana Limited, India). Laboratory-prepared tablets were made, containing $10 \mathrm{mg}$ of NEB and $10 \mathrm{mg}$ of AML, Starch maize $50.0 \mathrm{mg}$, Hydroxypropyl Methyl Cellulose $45.0 \mathrm{mg}$, Lactose Monohydrate $70.0 \mathrm{mg}$, Croscarmellose Sodium $15.0 \mathrm{mg}$, Microcrystalline Cellulose $38.0 \mathrm{mg}$, Silicon Dioxide $5.0 \mathrm{mg}$ and Magnesium Stearate $2.2 \mathrm{mg}$ per tablet. All used chemical substances and chemical reagents were procured as analytical reagent grade. Ultra pure water was obtained using an aquaMAX ${ }^{\mathrm{TM}}$ (Younglin Instrument, Korea) water purification system for HPLC.

\section{Chromatographic Conditions and Instrumentation}

Shimadzu HPLC, Binary Pump (Shimadzu, Kyoto, Japan) was used for the chromatographic separation. The HPLC chromatographic system was established using the following parts: SPD M20A photodiode array (PDA) detector, SIL 20AC Autosampler, LC 20AB pump and CTO-10As column oven. Data gathered and derived from chromatographic procedure was processed by the software of the same chromatographic system. Separation of substances in chromatographic system was performed on a Phenomenex Kinetex $150 \mathrm{~mm}$ x $4.6 \mathrm{~mm}, 2.6$ $\mu \mathrm{C} 18(4.0 \times 100 \mathrm{~mm}, 3 \mu \mathrm{m})$ using a mobile phase consisting

(A) Nebivolol

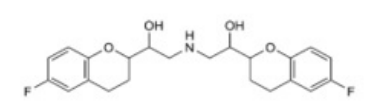

(C)Amlodipin

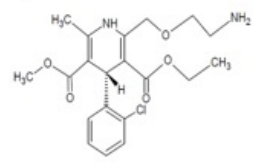

(B) Nebivolol impurity A

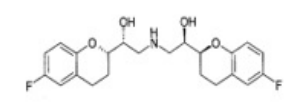

(D) Amlodipin impurity D

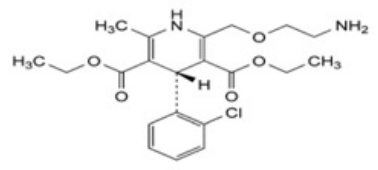

(E) Amlodipin impurity E

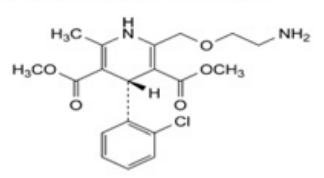

Figure 1. Chemical structures: NEB and AML and some related compounds

NEB: Nebivolol, AML: Amlodipine 
of a mixture of acetate buffer ( $\mathrm{pH}: 4.5)$ and acetonitrile with gradient elution on a consistent flow rate of $1.3 \mathrm{~mL} / \mathrm{min}$. Specific wavelength of $265 \mathrm{~nm}$ was selected for PDA detection. Temperature Column was kept at $35^{\circ} \mathrm{C}$.

\section{Standard Solution Preparation}

Stock solution of $500.0 \mu \mathrm{g} / \mathrm{mL}$ NEB and impurity of NEB A, AML and impurity of AML D and E were formed through dissolution of reference standard materials of the investigated pharmaceutical active ingredients and related compounds in $100 \mathrm{~mL}$ of acetonitrile: acetate buffer ( $\mathrm{pH}: 4.5)(50: 50, \mathrm{v} / \mathrm{v})$ in a calibrated flask using an ultrasonic bath. Working standard solutions were formed through adequate dilution of the stock solution with the above mentioned solution mixture. Stock solutions were kept at $4{ }^{\circ} \mathrm{C}$ and were stable for a month.

Ammonium acetate of $1.5 \mathrm{~g}$ was accurately weighed and dissolved in $1,000 \mathrm{~mL}$ of water to get $20 \mathrm{mM}$ of solution for the buffer solution preparation. The $\mathrm{pH}$ of the final solution was adjusted to 4.5 with acetic acid. It was then filtered with a $0.22 \mu$ filter. The filtered solution was degassed and used as a buffer in the mobile phase.

\section{General Procedures}

\section{Construction of the Calibration Curves}

Accurately measured aliquots of NEB and AML standard solutions covering the working concentration ranges of $0.20-10.0 \mu \mathrm{g} / \mathrm{mL}$ and $0.25-10.00 \mu \mathrm{g} / \mathrm{mL}$ were prepared, respectively, and then transferred into a series of $10 \mathrm{~mL}$ volumetric flasks. Solutions were diluted to the mark with acetonitrile: acetate buffer $(\mathrm{pH}$ : 4.5) (50:50, v/v) and mixed well. Related compounds of NEB A, AML D and E stock solutions were formed through diluting 1 $\mathrm{mg}$ of related compounds in $1 \mathrm{~mL}$ of acetonitrile: acetate buffer $(\mathrm{pH}: 4.5)(50: 50, \mathrm{v} / \mathrm{v})$ and further diluted with the same solvent. Stock solutions were stable when kept at $4^{\circ} \mathrm{C}$ in a refrigerator.

\section{Sample Preparation}

Fixed dose combination tablets with NEB and AML based on a ratio of 1:1 were prepared in the laboratory. An accurate amount of prepared tablets having equivalent milligrams of active ingredients of $10 \mathrm{mg}$ of NEB and $10 \mathrm{mg}$ of AML (in line with their ratio in the pharmaceutical formulation) was weighed and transferred into a $100 \mathrm{~mL}$ volumetric flask, and the volume was completed to final a volume of $100 \mathrm{~mL}$ with acetonitrile: acetate buffer ( $\mathrm{pH}: 4.5)$ (50:50, v/v). Flasks were kept in an ultrasonic bath for $30 \mathrm{~min}$ to best dissolve the contents, and then the content was filtered by $0.45 \mu \mathrm{m}$ membrane polytetrafluoroethylene. The above mentioned procedure was implemented to construct the calibration curves. The quantification of the nominal value of each compound within the content was calculated based on the established calibration curve or the corresponding regression equation.

\section{Validation of Analytical Method}

The analytical method development and validation were carried out in line with the ICH guidelines (23). Methods were validated based on the parameters covering quantification, accuracy, precision, specificity, linearity, range and detection limit.

\section{Specificity}

Stress degradation investigation was carried out in line with the ICH guidelines Q1A (R2) (23) to show the stability-defining characteristic and specificity of the developed analytical method. Solutions from tablet preparation were investigated under various forced degradation conditions described as follows: under alkaline conditions $(1 \mathrm{~N}$ sodium hydroxide $(\mathrm{NaOH})$ at ambient temperature in 24 hours), acidic conditions ( $1 \mathrm{~N}$ hydrogen chloride $(\mathrm{HCl})$ at ambient temperature in 24 hours), neutral conditions (water at $70{ }^{\circ} \mathrm{C}$ in 1 hour) and oxidative conditions (3.0\% v/v $\mathrm{H}_{2} \mathrm{O}_{2}$ at ambient temperature in 3 hours). Samples from alkaline and acidic degradation stress conditions were neutralised using adequate amount of $1 \mathrm{~N} \mathrm{HCl}$ and $1 \mathrm{~N}$ $\mathrm{NaOH}$, respectively, and completed to the end volume with the diluent. Thermal stress conditions were created by keeping the investigational medicinal product in heat controlled oven at 80 ${ }^{\circ} \mathrm{C}$ in a week. The pharmaceutical preparation was exposed to ultraviolet lamp for 72 hours to check the photostability. Upon completion of pre-defined time, solutions resulting from stress condition testing were diluted with the methanol: acetate buffer $(\mathrm{pH}: 4.5)(50: 50, \mathrm{v} / \mathrm{v})$, and samples for degradation testing were subjected to analysis by the developed HPLC method as mentioned in the chromatographic condition section. A PDA detector was used to define peak purity concerning peaks resulting from all samples from stress condition testing.

Specificity is the ability of the method to measure the analyte response in the presence of all related substances (NEB A, AML $\mathrm{D}$ and $\mathrm{E})$. For specificity determination, all related substances were prepared individually and injected into HPLC to confirm retention times. Later on, solutions of blank, sample and spiked sample (sample spiked with all related substances) were prepared and injected into HPLC to confirm any co-elution with analyte peaks from respective blank and any degradation peaks. From the injections of spiked sample, the known related substance peaks were confirmed to be well separated from each other and without collation, showing that the method is selective and specific. The stability indicating nature of the method was further evaluated by performing forced degradation studies. Stress testing was carried out to identify the likelihood degradation products or to elucidate the inherent stability characteristics of drug substance. In this study, drug was subjected to oxidation, hydrolytic, photolytic, thermal and humidity stress conditions, and the summary of results obtained from forced degradation experiment results is presented in Table 4. Results showed that peaks were found stable in all forced degradation conditions, without interference for related compound peaks from other peaks.

\section{Linearity}

The linearity of the method was established for drugs and their related compounds. Drugs solution and their related compounds were formed at five various concentrations within the range of 0.20 and $15.00 \mu \mathrm{g} / \mathrm{mL}$ of concentration of analyte. The regression line was constructed between the peak area and 
corresponding analyte concentration based on method of least squares analysis. The slope and Y-intercept values of regression line were calculated.

\section{Limit of Quantitation (LOQ) and Limit of Detection (LOD)}

LOQ and LOD were calculated as the 10 and 3.3 times of the standard deviation of the peak area divided by the slope of the linearity calibration curve, respectively.

\section{Precision}

Method precision and accuracy were determined as within and between the days of precision. The within and between the day precision values were investigated at three different concentrations $(n=5)$ of the analyte during five consecutive days. The relative standard deviation (RSD) was provided as the precision value.

\section{Accuracy}

Recoveries by spiking method were used for method accuracy calculation. Standard solutions with known amount (low, medium and high concentrations) were spiked with sample solutions of known amount $(0.2 \mu \mathrm{g} / \mathrm{mL})$. The regression equation of the calibration curve was used to estimate the spiked amount.

\section{Robustness}

Investigation of the robustness of the method was performed through deliberate modification of key method conditions like organic phase composition, flow rate of the mobile phase and key method parameters, such as selected wavelength for detection. Investigation of drug solution stability in mobile phase was performed by keeping the drug solution in ambient temperature for one day, $24 \mathrm{~h}$.

\section{Results}

\section{Chromatographic Conditions}

Separation in proposed chromatography system was performed on C18 column (150 mm x $4.6 \mathrm{~mm}, 2.6 \mu \mathrm{m})$ using a gradient elution system. For this procedure, the mobile phase consisting of a mixture of acetate buffer ( $\mathrm{pH}: 4.5)$ and acetonitrile was formed, and the flow rate was determined as $1.3 \mathrm{~mL} / \mathrm{min}$. The wavelength of $265 \mathrm{~nm}$ was selected for PDA detection. The column temperature was kept at $35{ }^{\circ} \mathrm{C}$ during the procedure. Table 1 presents the gradient elution programme. Figure 2 presents the typical chromatograms.
Five replicates of freshly prepared substances were injected to evaluate the method adequacy for resolution between targeted peaks with high level of repeatability. The chromatogram was analysed based on the following factors: resolution (R), theoretical plates $(\mathrm{N})$, tailing factor, retention time $(\mathrm{tR})$ and symmetry factor $(\alpha)$. The system suitability test results proved that the developed method in this present article comply with the acceptable limits described by the requirements (Table 2).

\section{Method Validation}

$\mathrm{ICH}$ guidelines were the basis of method validation and optimisation (23). As described in the guideline, parameters consisting precision, accuracy, robustness, specificity, linearity, LOD and LOQ were investigated.

\section{Linearity}

The linearity of the method was tested both for the individual drug substances and their related compounds in the combination formula. Five different concentrations of drug solutions and impurity solutions were prepared. The concentration range of the analyte varied from 0.20 to $15.00 \mu \mathrm{g} / \mathrm{mL}$. The calibration

Table 1. Gradient elution programme

\begin{tabular}{|l|l|l|}
\hline Time & Acetate buffer $(\mathrm{pH}: 4.5)$ & Acetonitrile \\
\hline 0 & 80 & 20 \\
5 & 80 & 20 \\
40 & 35 & 65 \\
45 & 80 & 20 \\
50 & 80 & 20 \\
\hline
\end{tabular}

(A)

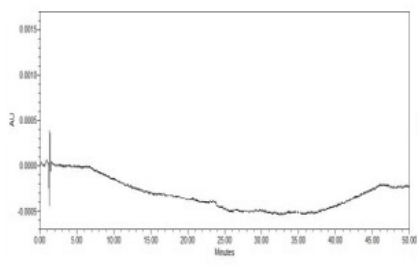

(B)

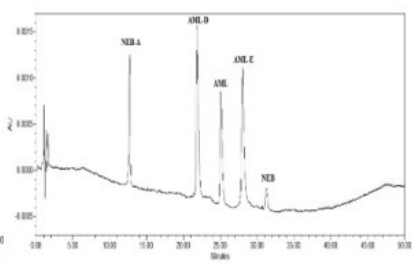

Figure 2. Representative chromatograms of (A) blank, (B) AML $0.2 \mu \mathrm{g} / \mathrm{mL}$, NEB $0.5 \mu \mathrm{g} / \mathrm{mL}$ and related compounds spiked with $0.5 \mu \mathrm{g} / \mathrm{mL}$

NEB: Nebivolol, AML: Amlodipine

\begin{tabular}{|c|c|c|c|c|c|c|}
\hline NEB & $31.094 \pm 0.001$ & 1.09 & $33260 \pm 345$ & 1.04 & $4.93 \pm 0.05$ & 1.04 \\
\hline NEB Imp A & $12.686 \pm 0.001$ & 0.96 & $23544 \pm 158$ & 0.59 & $5.76 \pm 0.03$ & 0.59 \\
\hline AML & $25.104 \pm 0.002$ & 1.39 & $36758 \pm 419$ & 1.20 & $6.31 \pm 0.08$ & 1.20 \\
\hline AML Imp D & $21.881 \pm 0.002$ & 1.42 & $30772 \pm 320$ & 1.04 & $22.19 \pm 0.23$ & 1.04 \\
\hline
\end{tabular}


curve was plotted by drawing the corresponding impurity peak area against the concentration on the chart. The calculated coefficients of correlation, slopes of the curves, and y-intercepts of the calibration plots were presented. Calibration curves concerning the related substances were determined to be linear within the ranges involved in the study. Correlation coefficients were found to be $>0.9990$ for all molecules of interest (Table 3).

The LOQ and LOD were measured following a recommended formula (according to ICH Q2 (R1) (23) shown as

$$
\mathrm{LOD}=3.3 \mathrm{SD} / \text { slope } \mathrm{LOQ}=10 \mathrm{SD} / \text { slope } \quad \text { (Eq. } 1)
$$

where SD is the standard deviation of the intercept and standard deviation of the peak area. The LOD and LOQ values presented in Table 3 prove that the proposed methods are adequately sensitive for determination of these drugs.

\section{Precision}

The precision trials were performed by a sequence of analyses of AML and NEB and related compounds for five consecutive days (each $\mathrm{n}=5$ ). The RSD values were found in the range from $0.59 \%$ to $1.34 \%$ for intraday precision and from $1.11 \%$ to $1.61 \%$ for the interday precision. All values were found to be $<2 \%$, proving that the method was adequately precise. Results are presented in Table 3 .

\section{Specificity}

Forced degradation under various experimental conditions was investigated using a starting concentration of $1 \mathrm{mg} / \mathrm{mL}$ of the sample. A PDA detector was used to ensure the homogeneity of drug peaks. After subjecting the drug to acid and base hydrolysis and oxidative degradation, the degradation products of NEB, Imp $A$ and AML Imp D were observed. The thermal and water hydrolysis and the photolytic stress study showed that AML was degraded into AML Imp D (Figure 3). These results confirmed that the drug product maintained its stability well when exposed to forced degradation tests (Table 4).

\section{Accuracy}

The standard addition technique was used to prove the accuracy of the method. Certain amount $(0.2 \mu \mathrm{g} / \mathrm{mL})$ of pure sample solution were added to three concentration level of the drug standard solutions and related compounds (low, medium and high concentration) and analysed. Percentage recoveries for the drug and related compounds were within the range of $98.00 \%$ $101.50 \%$. Results of recovery study were presented in Table 5.

\section{Robustness}

The method was evaluated to be robust based on the findings after making intentional changes in the process; including flow rate of the mobile phase $( \pm 0.1 \mathrm{~mL} / \mathrm{min})$, mobile phase $\mathrm{pH}$
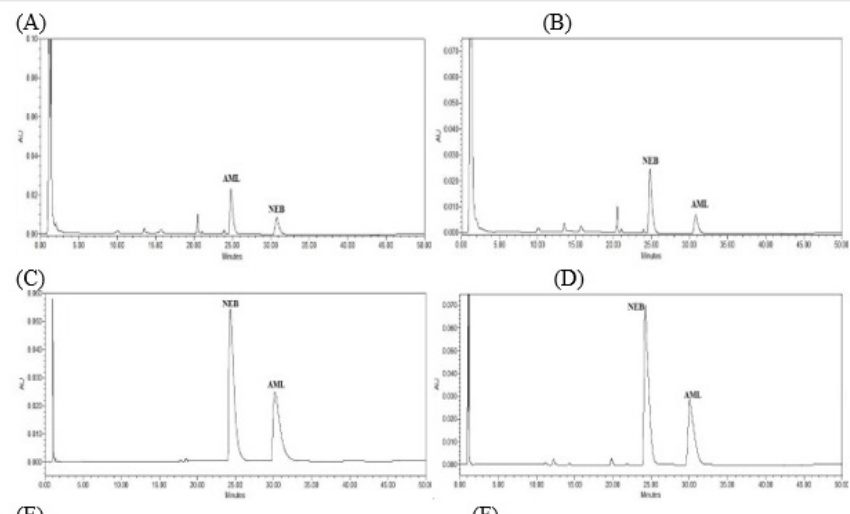

(D)
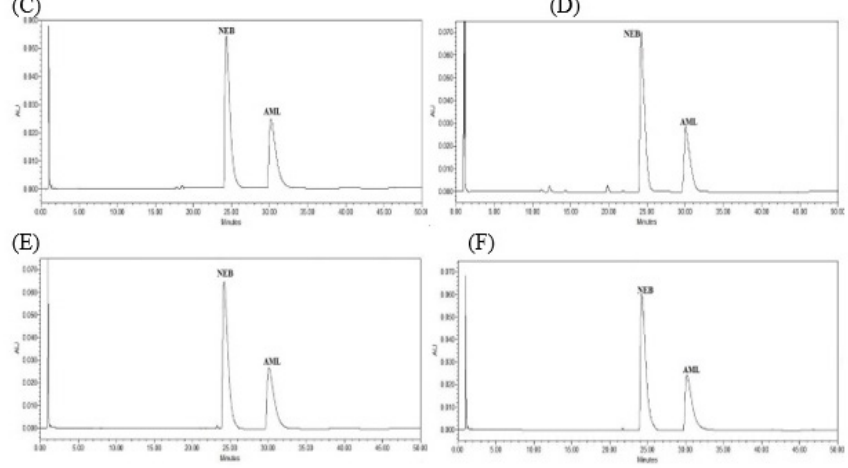

(F)

Figure 3. Chromatograms of AML and NEB at synthetic mixture (A) acid-degraded drug, (B) base-degraded drug, (C) water hydrolysis-degraded drug, (D) oxidation-degraded drug, (E) thermal-degraded drug and (F) daylight-degraded drug

NEB: Nebivolol, AML: Amlodipine

Table 3. Regression, precision, limit of detection (LOD) and limit of quantification (LOQ) data

\begin{tabular}{|c|c|c|c|c|c|}
\hline Parameter & NEB & NEB Imp A & AML & AML Imp D & AML Imp E \\
\hline Slope & 1368748 & 1775624 & 2450505 & 3116410 & 1933305 \\
\hline Intercept & 176 & -182 & -371 & -358 & -561 \\
\hline Linearity range $(\mu \mathrm{g} / \mathrm{mL})$ & $0.20-10.00$ & $0.20-10.00$ & $0.25-10.00$ & $0.30-10.00$ & $0.40-15.00$ \\
\hline LOD & 0.05 & 0.05 & 0.06 & 0.04 & 0.03 \\
\hline LOQ & 0.17 & 0.17 & 0.20 & 0.13 & 0.10 \\
\hline Intraday precision (RSD) ${ }^{\mathrm{a}}$ & 1.04 & 0.59 & 1.20 & 1.04 & 1.34 \\
\hline $\begin{array}{l}\text { Interday precision (RSD) } \\
{ }^{\mathrm{b}} \mathrm{n}=5 \\
{ }^{\mathrm{b}} \text { Results of five different days }\end{array}$ & 1.13 & 1.36 & 1.14 & 1.61 & 1.11 \\
\hline
\end{tabular}


$(4.5 \pm 0.1)$ and column oven temperature $\left(35 \pm 2{ }^{\circ} \mathrm{C}\right)$. Some minor variations were observed in the proposed method; however, variables did not significantly affect the outcome. We concluded that the obtained data proved the robustness of the proposed method in this article.

The chemical stability of the stock solutions of the studied compounds has been tested to determine the outcomes of storage for 48 hours at room temperature $\left(25^{\circ} \mathrm{C}\right)$. All compounds were found to be stable in the mobile phase for 48 hours at room temperature, and were also stable in the refrigerator $\left(4^{\circ} \mathrm{C}\right)$. No unexpected peaks were detected in the chromatograms during the stability studies.

\section{Analysis of Synthetic Mixture}

The proposed method was implemented for the quantitation of NEB and AML and their related compounds using the synthetic mixture sample. The obtained results are in line with the labelled content for NEB and AML combination formula. Furthermore, the related chemical related compounds were found at levels below the acceptable limit.

\section{Conclusion}

In this article, validated HPLC method was presented to determine and quantify NEB, AML, and some related compounds in a synthetic mixture. This method was evaluated for linearity,

Table 4. Forced degradation results

\begin{tabular}{|c|c|c|c|c|c|}
\hline Stress condition & Degradation (\%) & $\begin{array}{l}\text { Number of } \\
\text { impurities }\end{array}$ & Retention time (min) & $\begin{array}{l}\text { Peak purity } \\
\text { (Amlodipin) }\end{array}$ & $\begin{array}{l}\text { Peak purity } \\
\text { (Nebivolol) }\end{array}$ \\
\hline Acidic/1N HCl/RT/24 h & 15.5 & 7 & $\begin{array}{l}\text { 10.038;12.663; } 13.537 ; 15.719 ; \\
20.489 ; 21.029 ; 23.927\end{array}$ & 0.99965 & 0.99975 \\
\hline Alkaline/1N NaOH/RT/24 h & 16.4 & 7 & $\begin{array}{l}\text { 10.072;12.695; 13.539;15.715; } \\
20.489 ; 21.047 ; 23.928\end{array}$ & 0.99981 & 0.99971 \\
\hline Oxidation/3\% H2O2/3 h & 6.5 & 9 & $\begin{array}{l}11.158 ; 11.737 ; 12.244 ; 14.297 ; \\
16.541 ; 16.983 ; 19.282 ; 19.763 ; 21.822\end{array}$ & 0.99977 & 0.99967 \\
\hline Neutral/ $\mathrm{H} 2 \mathrm{O} / 70^{\circ} \mathrm{C} / 1 \mathrm{~h}$ & 0.4 & 6 & $\begin{array}{l}8.016 ; 17.808 ; 18.474 ; 19.182 \\
20.065 ; 21.819\end{array}$ & 0.99972 & 0.99962 \\
\hline Photolytic/UV-lamp/72 h & 1.3 & 10 & $\begin{array}{l}8.731 ; 10.323 ; 15.963 ; 16415 ; \\
16.885 ; 17.651 ; 18.475 ; 19.190 ; \\
20.070 ; 21.737\end{array}$ & 0.99989 & 0.99985 \\
\hline Thermal $/ 80^{\circ} \mathrm{C} / 1$ week & 0.9 & 9 & $\begin{array}{l}17.419 ; 17.881 ; 18.225 ; 19.165 \\
19.554 ; 20.023 ; 21.206 ; 21.860\end{array}$ & 0.99990 & 0.99983 \\
\hline
\end{tabular}

Table 5. Results of recoveries data of AML, NEB and related compounds

\begin{tabular}{|c|c|c|c|c|c|}
\hline Analyte & $\begin{array}{l}\text { Amount of drug taken } \\
(\mu \mathrm{g} / \mathrm{mL})\end{array}$ & $\begin{array}{l}\text { Amount of drug spiked } \\
(\mu \mathrm{g} / \mathrm{mL})\end{array}$ & $\begin{array}{l}\text { Total amount found }(\mu \mathrm{g} / \mathrm{mL}) \\
\left.\text { (Mean } \pm \mathrm{SD}^{c}\right)\end{array}$ & Recovery (\%) & $\mathrm{RSD}^{\mathrm{d}}$ \\
\hline \multirow{3}{*}{ Nebivolol A } & \multirow{15}{*}{0.2} & 0.36 & $0.53 \pm 0.0058$ & 99.6 & 1.09 \\
\hline & & 4.30 & $4.48 \pm 0.0140$ & 99.5 & 0.31 \\
\hline & & 6.55 & $6.72 \pm 0.0210$ & 99.5 & 0.31 \\
\hline \multirow{3}{*}{ Amlodipine D } & & 0.21 & $0.41 \pm 0.0053$ & 100.0 & 1.29 \\
\hline & & 4.80 & $5.13 \pm 0.0300$ & 100.6 & 0.59 \\
\hline & & 7.30 & $7.50 \pm 0.0430$ & 98.0 & 0.57 \\
\hline \multirow{3}{*}{ Amlodipine $\mathrm{E}$} & & 0.70 & $0.89 \pm 0.0079$ & 98.8 & 0.89 \\
\hline & & 4.80 & $4.97 \pm 0.0210$ & 99.5 & 0.42 \\
\hline & & 7.30 & $7.46 \pm 0.0320$ & 99.5 & 0.42 \\
\hline \multirow{3}{*}{ Amlodipine } & & 0.70 & $0.50 \pm 0.0053$ & 99.0 & 1.06 \\
\hline & & 4.80 & $5.04 \pm 0.0280$ & 101.5 & 0.55 \\
\hline & & 7.30 & $7.56 \pm 0.0420$ & 101.5 & 0.56 \\
\hline \multirow{3}{*}{ Nebivolol } & & 0.65 & $0.85 \pm 0.0077$ & 100.5 & 0.91 \\
\hline & & 1.80 & $2.01 \pm 0.0048$ & 101.1 & 0.24 \\
\hline & & 2.80 & $3.02 \pm 0.0073$ & 101.1 & 0.25 \\
\hline
\end{tabular}


precision, accuracy, LOD, LOQ, selectivity, robustness and solution stability. The selectivity of the method is evaluated as per ICH guidelines by carrying out forced degradation tests of NEB and AML combination tablets. Outcomes of these tests demonstrated that the method was stable based on the findings of NEB and AML-related substances. Thereby, we concluded that the developed and validated method proposed in this current article could be widely used in the routine practice to simultaneously determine NEB and AML and their related compounds in the synthetic mixture.

Peer-review: Externally peer review.

\section{Authorship Contributions}

Concept: C.Ö., K.A., A.Ö., Design: C.Ö., K.A., A.Ö., Data Collection or Processing: C.Ö., K.A., Ç.A., A.Ö., Analysis or Interpretation: C.Ö., K.A., Ç.A., Literature Search: C.Ö., K.A., Ç.A., A.Ö., Writing: C.Ö., K.A.

Conflict of Interest: No conflict of interest was declared by the authors.

Financial Disclosure: The authors declared that this study received no financial support.

\section{References}

1. Bowman AJ, Chen CP, Ford GA. Nitric oxide mediated venodilator effects of nebivolol. Br J Clin Pharmacol 1994;38:199-204.

2. Agabiti Rosei E, Rizzoni D. Metabolic profile of nebivolol, a beta-adrenoceptor antagonist with unique characteristics. Drugs 2007;67:1097-107.

3. Weiss R. Nebivolol: a novel beta-blocker with nitric oxide-induced vasodilatation. Vasc Health Risk Manag 2006;2:303-8.

4. O’Neil MJ, Heckelman PE, Koch CB, Roman KJ, editors. TheMerck Index.14th ed. An encyclopedia of chemicals, drugs, andbiologicals. USA, NJ: Merck Research Laboratories, Merck\&Co Inc Whitehouse Station; 2006.

5. Mason RP, Marche P, Hintze TH. Novel vascular biology of thirdgeneration L-type calcium channel antagonists: ancillary actions of amlodipine. Arterioscler Thromb Vasc Biol 2003;23:2155-63.

6. Stepien O, Zhang Y, Zhu D, Marche P. Dual mechanism of action of amlodipine in human vascular smooth muscle cells. J Hypertens 2002;20:95-102.

7. Chandnani VC, Gupta K, Chopde C, Kunjwani H, Manikaroa A, Shivhare S. Simultaneous UV Spectrophotometric Determination of Amlodipine Besylate and Nebivolol $\mathrm{HCl}$ in Tablet Dosage Form. Int J Chem Tech Res 2010;2:69-73.

8. Nikalje APG, Choudharia VP, Kulkarni RR, Chaudhari V, Parakh S. Iso absorptive point and zero absorbance spectrophotometric methods for estimation of nebivolol and amlodipine in combination in tablet formulation. Int J Chem Sci 2007;5:396-402.

9. Mishra P, Shah K, Gupta A. Spectrophotometric Methods for Simultaneous Estimation of Nebivolol Hydrochloride and Amlodipine Besylate in Tablets. Int J Pharm Sci 2008;1:55-61.
10. Joshi HV, Patel JK, Patel MP, Wankhede S. Simultaneous estimation of Nebivolol and S-Amlodipine in tablets by UV-Spectrophotometry. Der Pharma Chemica 2010;2:105-8.

11. Patel SA, Patel PU, Patel NJ. Absorbance correction method for simultaneous determination of nebivolol and amlodipine besylate in combined tablet dosage form. Int Res J Pharm 2011;2: 92-5.

12. Patel SR, Patel SM, Patel JI, Patel PU. Simultaneous determination of nebivolol and amlodipine in combined dosage form by derivative spectrophotometry. Res J Pharm Tech2011;4: 109-112.

13. Patil PB, Chavan CB, Jagtap DA, Mohite SK, Magdum CS. Simultaneous estimation of nebivolol hydrochloride and amlodipine besylate by UV spectrophotometric method. Int J ChemTech Res 2012;4:1241-6.

14. Joshi SJ, Karbhari PA, Bhoir SI. RP-LC simultaneous determination of nebivolol hydrochloride and amlodipine besylate in bi-layer tablets. Chromatographia 2009;70:557-61.

15. Sharma A, Patel B, Patel R. Simultaneous estimation of nebivolol hydrochloride and S-amlodipine besylate by high performance thin layer chromatography. Int J Pharm Bio Sci 2010;1:339-47.

16. Deepak S, Anurekha J, Alankar S. Simultaneous estimation of amlodipine besylate and nebivolol hydrochloride in tablet dosage forms by reverse phase-high-performance liquid chromatographic using ultraviolet detection. Pharm Method 2011;2:9-14.

17. Jain M, Tiwari S, Mishra VK, Shukla S, Sheikh S. (2010). Simultaneous estimation of amlodipine besylate and nebivolol hydrochloride in combined dosage form by RP-HPLC. Int J Pharm Life Sci 2010;1:428-32.

18. Kolasani A, Kumar GVS, Puranik SB, Sridhar KA. (2012). Stability Indicating HPLC Method for Estimation of S-Amlodipine Besilate and Nebivolol hydrochloride in Bulk Drugs and Marketed Formulation. Int J Pharm ResScholars 2012;1-3:217-23.

19. Dhandapani B, Anjaneyulu N, Venkateshwarlu Y, Rasheed SH. HPTLC method development and validation for the simultaneous estimation of amlodipine besylate and nebivolol hydrochloride in tablet dosage form. J Pharm Res 2010;3:332-4.

20. Patel SR, Patel SM, Patel JI. Patel PU. Development and validation of high-performance thin-layer chromatography method for determination of nebivolol and amlodipine in combined dosage forms. J Pharm Res 2010;3:2273-5.

21. Sharma AK, Patel B, Rakshit P. Simultaneous estimation of nebivolol hydrochloride and S-amlodipine besylate by high performance thin layer chromatography. Int J Pharm Bio Sci 2010;1:339-47.

22. Sharma AK, Bhavesh P, Rakshit P. HPTLC determination of compound formulation of Nebivolol hydrochloride and S-Amlodipine besylate. Rec Prog Med Plant 2011;31:161-70.

23. ICH. Q2 (R1) Validation of Analytical Procedures: Text and Methodology. International Conference on Harmo-nization. Geneva: November 2005, p. 1-13. 